\title{
Impact of Migration to Livehood and Agricultural Land of Indigenous Forest-Dependent Communities in North Kalimantan, Indonesia
}

\author{
Ndan Imang ${ }^{1}$ Martinus Nanang ${ }^{2}$ Rujehan $^{3, *}$ \\ ${ }^{1}$ Faculty of Agriculture, Mulawarman University, Samarinda, East Kalimantan, Indonesia \\ ${ }^{2}$ Faculty of Social and Political Mulawarman University, Samarinda, East Kalimantan, Indonesia \\ ${ }^{3}$ Faculty of Forestry Mulawarman University Samarinda, East Kalimantan, Indonesia \\ *Corresponding author. Email: rujehan56@gmail.com
}

\begin{abstract}
This research was conducted in 2017 at four forest-dependent villages of Kalimantan, Indonesia, which were traditionally migrated outside village looking for a job. This study aims to determine the impact of migration on the livelihood and agricultural land of forest-dependent farmers. The result showed that cash and remittance from outmigrants do not negatively affect forests and land. During 2000-2016, cash and remittance were decreased. Still, cash made-home tends to increase. The educated in-migrant people had a positive impact on education sharing. No negative impact on forests and land, out-migration did not reduce agricultural production, and the prospect of outmigration to seek a good job out-side Indonesia showed the respondents no longer interested because of Indonesia's availability of opportunities the decentralization policy since 2000 .
\end{abstract}

\section{Keywords: Migration, Remittance, Social Culture, Local Policy}

\section{INTRODUCTION}

The growth rate of migration from one place to another increases rapidly. Migration itself is a way of life, an investment, and a strategy to defend against the changes. Further, migration is often viewed as the best option for poor rural households to exit from poverty [1]. People generally migrate from one place to another primarily for economic reasons to gain a better living and improve their economic conditions. Migration has impacts on the economies that people leave and those in which they re-settle. These effects vary with different types of migration, the skills of the migrants, and the lengths of time involved [2,3].

Nevertheless, there are times when people migrate with economic motives and non-economic motives, such as continuing education to increase their knowledge. Motives like this are usually driven by open access to information from outside and increasing development in a region. Infrastructure improvement and transportation, which usually accompany development, make travel less costly and risky, thus enabling migration over increasing distances [4]. Those who take advantage of this opportunity are generally dominated by young people, while their parents are still working in agriculture fields. Such conditions will certainly impact changes in community behavior related to the sustainability of forest and land management.

Forests can provide tangible and intangible benefits to local communities. However, these benefits can be achieved and maintained if people manage forests properly and continuously. Well-managed forests will improve their function, both production function and protection function [5]. But a good forest is not necessarily able to provide the immediate benefits needed for the people around it. Humans play an important role in managing forest resources, especially for rural communities, because their lives depend more on arable land availability [6].

The preservation of forest functions will be disturbed if the community feels dissatisfied with what they have done. To achieve these expectations, the choice to migrate becomes an alternative that may bring changes in their lives. Migration is a strategy undertaken by people everywhere to improve their livelihoods that often occur when their income sources are more limited $[7,8,9]$. In agrarian societies, migration is a strategy that 
they do to improve their lives, and to some others, they survive when the land they depend on is increasingly limited [10]. The choice of migrating out of the region will have a disproportionate impact on farmer households. Some family members living in the village should be responsible for land management activities. The division of labor between husbands, wives, and grown-up children in migrating households also occurs. Often, family members residing in the village have more responsibility for managing the land.

For some households in research sites, remittances are one of their sources of income which they use for various purposes. Some of them receive remittances regularly in a certain amount. But, for some other families, remittances can only be used when the migrated family members returned home or accumulated a sufficient amount of money to transfer to their family. For farmer households, this uncertaintyincome encourages them to seek alternative income sources, such as using forest products. This research aims to know the impact of out and in-migration on local livelihood and forest land management.

\section{METHODOLOGY}

Field observation was conducted from February 2017 to May 2017 in Malinau District of North Kalimantan Province, Indonesia. Malinau District is adjacent to neighborhood country Malaysia, so that Malinau District has a strategic position for traditional cross-boundary or out-migration from Indonesia to Sarawak Malaysia (Figure 1).

The reason to select the villages for research is that there is an on-ground project of the Forests and Climate Change Program (FORCLIME), currently operating in the villages to benefit from the projects.

Primary data were collected through three mutually supportive means, and they are: (1) Focus Group Discussion (FGD) involved 20 people consisting of 10 men and ten women in each village; (2) in-depth interview with local government such as head of Subdistrict (Camat), village leader (Kepala Desa), community leaders; (3) individual interview with all 61 out-migrants and 25 in-migrants. The out-migrants were working or worked in Sarawak-Malaysia, Papua New Guinea, and Latin America. Descriptive qualitative analysis was used in this research.

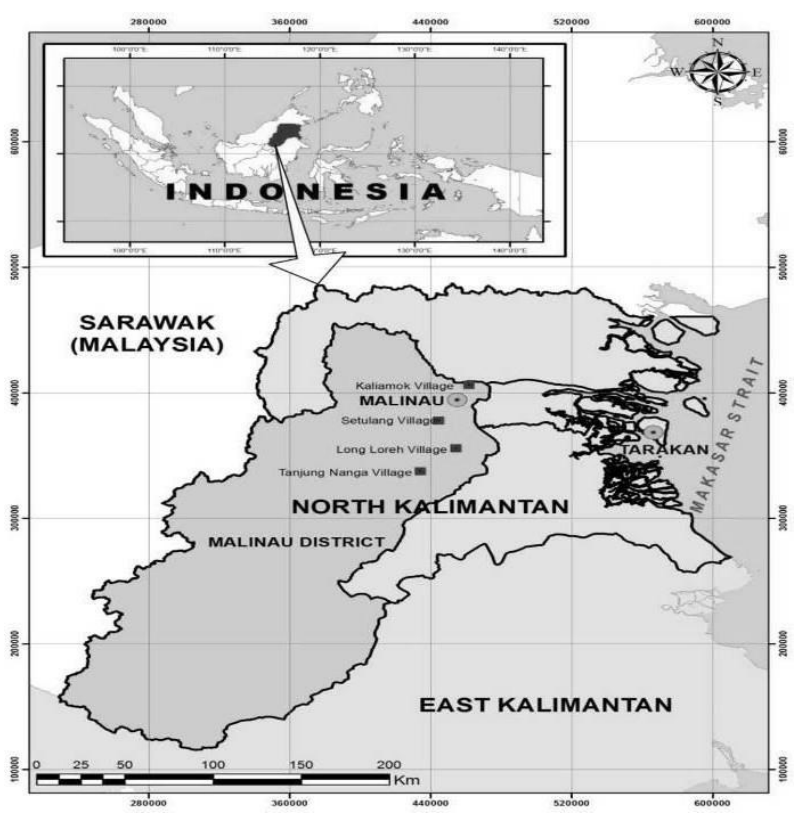

Figure 1 Study site map

\section{RESULT AND DISCUSSIONS}

Migration in this study, so-called meselai or peselai is an activity when someone, a group of men, leaves their village to look for a job in other countries. They usually spend more than one year working outside the village before they return home. Few would dispute that migration can be a rational response to poverty and limited life opportunities. More educated (relative to their peers) and younger individuals migrate $[11,12]$. In the observed villages, forest and forest products play an important role in daily life, as shown in Table 1 below.

Table 1. The rank of forest products utilization

\begin{tabular}{lccccccc}
\hline \multirow{2}{*}{ Village } & \multicolumn{7}{c}{ Forest products utilization } \\
\cline { 2 - 8 } & Fire woods & Wood building material & NTFP & Hunts and Fish & Fruits & Vegetables & Honey \\
\hline Kaliamok & 1 & 4 & 5 & 2 & 3 & 6 & 7 \\
Long Loreh & 1 & 3 & 4 & 2 & 6 & 5 & 7 \\
Setulang & 2 & 4 & 1 & 3 & 6 & 5 & 7 \\
Tanjung Nanga & 1 & 5 & 3 & 2 & 4 & 6 & 7 \\
\hline
\end{tabular}

Source: Field survey (2017) 
Table 1 indicates that the most important forest products for collecting firewood and other non-timber forest products are hunting and fishing, and building materials.

\subsection{Impact of Out-Migration to Swidden Agriculture}

Out-migration may have profound effects on the size of forest and land for Swidden agriculture, household income and economy, structure, and population growth patterns. These effects may vary in time; also, for example, depending on the gender of migrants.

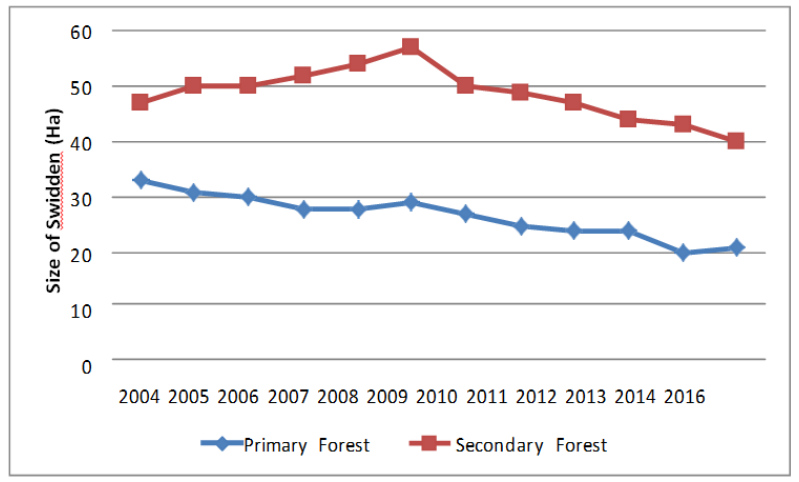

Figure 2 Forest for Swidden Agriculture

In the long run, it can affect population growth rates [3]. In terms of migration in four research sites, we described some effects: first, out-migration of the village affected the population and the number of family members in the village. Second, out-migration affected the agriculture production of the village. Rural labor out-migration led to a decline in agricultural cultivation and production. Rural households with labor migrants were found to have lower agricultural productivity than those without migratory workers. In this case, family labor working in agricultural fields and plantations was reduced because of the out-migration. This fact is in-line with [13]; swidden agriculture and other agricultural activities still play an important role in local livelihood in which most of their time was allocated for swidden. Some argue that out-migration may reduce agricultural workers. Some argued that after the out-migrants return home or transfer money, they would clear wider land for agriculture because they have more capital. Figure 2 shows that the size of both primary forest and young secondary forest shows a decreased trend. This means that cash and remittance from the out-migrants were used to expand agricultural area especially primary forests, and utilized for other non-agricultural purposes, such as education, improving houses, and running a small business for social and religious purposes.

\subsection{Impact of Out-Migration to Cash Income}



Note: IDR (Rp) 13,308 = USD 1 (May 2017)

Figure 3 Impact of out-migration to cash income

Traditionally, out-migrants purposes were to make cash income and buy capital properties such as a chainsaw and other machines that will be used to make money after returning home. For example, a chainsaw can be used and even hired to cut big trees in Swidden field or to make housing materials. During the outmigrant working outside the country, other family members living at home also work for cash income by their effort and using the money remitted by outmigrants (cash made at home), because remittances shift household spending from less productive asset accumulation to more productive asset accumulation [14]. From 2010 to 2016, we found that remittances were decreased, and on the other hand, cash made at home increased. This is because the opportunity to work at a private company in Sarawak-Malaysia during that time was decreased. Simultaneously, the opportunity to run a business or work on governmental projects increased after Indonesia's decentralization policy in 2000 .

\subsection{Impact of In-Migration to the Utilization of Forest and Land}

In some areas of Kalimantan Island, the presence of in-migrants caused competition overland with the local people who, in some cases, led to fighting with the newcomers. The migrant (newcomers) usually clear primary forest as wide as possible to have right over land. However, in this study, we found that from 2004 to 2016, the size of primary and secondary forests cleared by the in-migrants showed a decreasing trend.

We observed that the in-migrants are mostly educated people, such as teachers, nurses, and Preachers/Pastor. Since the beginning, they cleared the appropriate size of primary or old secondary forest and cleared smaller land for agricultural purposes in the following years. 


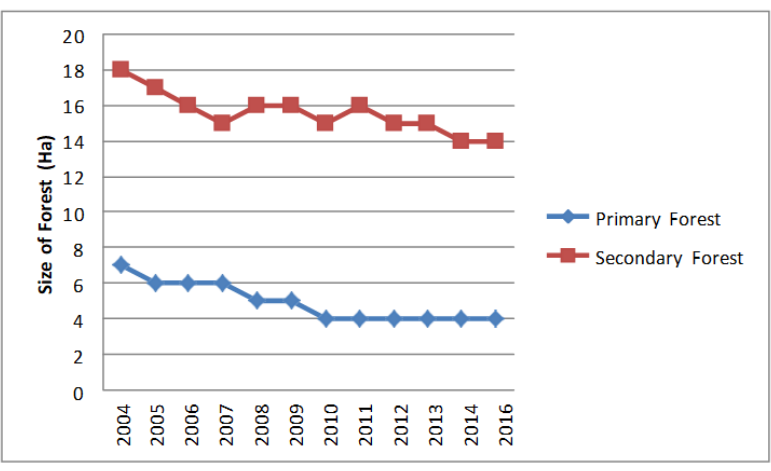

Figure 4 Impact of in-migration to the utilization of forest and land

\subsection{Impact of Out-Migration to Household Economy and Agricultural Production}

To know whether the economy and agricultural production level were increased or decreased, we interviewed all out-migrants. We put the answers using a Likert score (score of each question from 3-9). The scores' average accumulation was then categorized into three ranks: 3-4 decreased; 5-7 no change; 8-9 increased. In Setulang Village, Fig. 5 shows

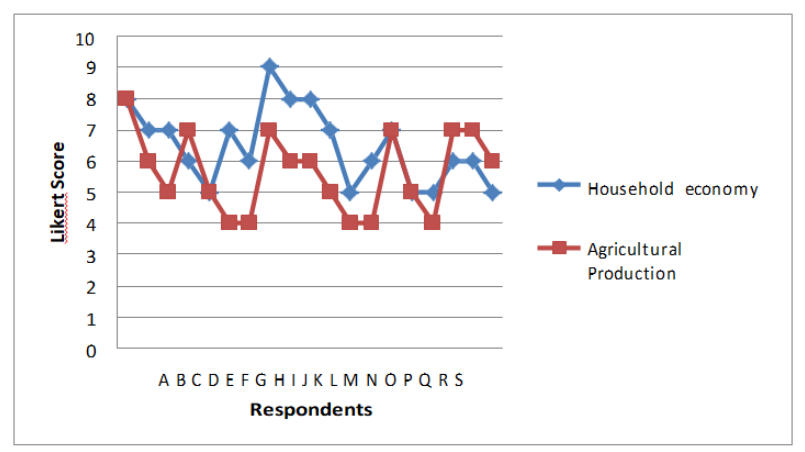

Figure 5 Impact of out-migration to household economy and agricultural production in Setulang

That out-migration caused a decrease of around $45 \%$ of respondents, and agricultural production of the rest, $55 \%$, showed no change or stability. The household economy (consisted of three indicators: house improvement, education for children, and cash) showed an increasing trend. This indicates that cash made by out-migrants could improve the household economy.

In Long Loreh Village (Fig. 6), the impact of outmigrants on the household economy and agricultural production showed the similarity with Setulang Village. Most respondents' agricultural productions were at the rank no-change, and the household economy showed no-change trends and increased. It means that outmigration has a positive impact on the household economy without impacting agricultural products.

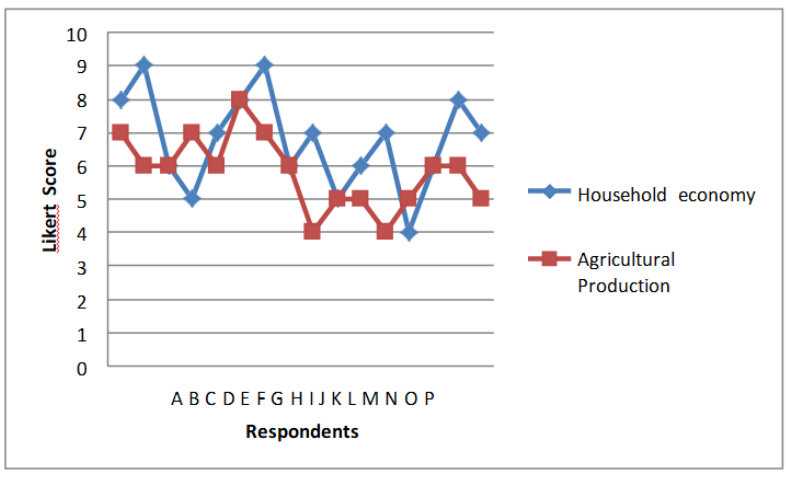

Figure 6 Impact of out-migration to household economy and agricultural production in Long Loreh

In the uppermost village Tanjung Nanga (Figure 7), the impact of out-migrants on the household economy showed that the household economy of $24 \%$ increased and $57 \%$ no-change and $19 \%$ decreased. Among the $57 \%$ of respondents mentioned above described that the out-migrants already spent a long time in Malaysia but were very rare to transfer money to family at home. In this matter, the family at homemade alternative efforts to keep and to improve the agricultural productions to feed family members.



Figure 7 Impact of out-migration to household economy and agricultural production in Tanjung Nanga

\subsection{The Prospect of Out-Migration}

Before Indonesia's decentralization policy in $1999 / 2000$, the research sites were quite isolated to Indonesian economic centers, and government projects were mostly centralized in town. Due to such a problem, rural people were very less enjoyed the result of the development, so they seek a good job outside Indonesia, especially in Sarawak-Malaysia.

To know the prospect of out-migration, we asked the respondent the question: "Do you still interested to seek a job outside Indonesia in the future?" We quantified their answers in scores: $1=$ not interested; $2=$ less interested; 3 = very interested. Figure 8 indicates that most respondents are no longer interested in doing outmigration or seeking a job outside Indonesia in four research sites. The important reason was during the decentralization era. They can work on government 
projects in the village to no longer be interested in working far away from their families.

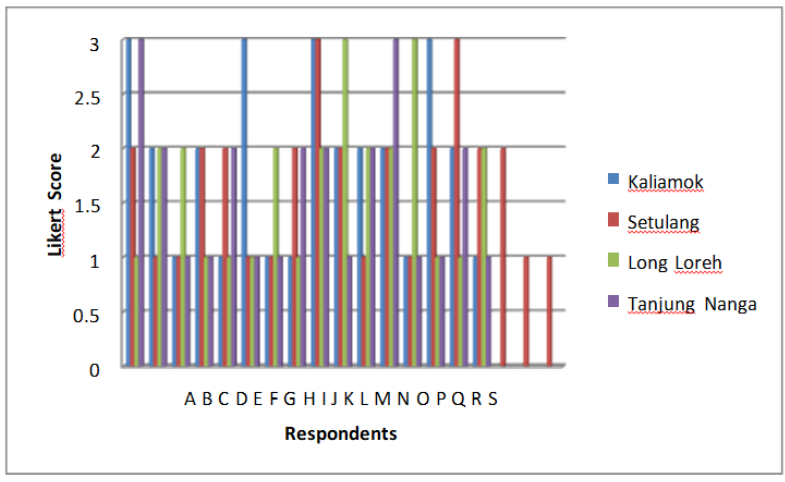

Figure 8 The future interest to work outside Indonesia

\section{CONCLUSIONS}

Cash and remittance from out-migrants had no negative effect on forest and land. During the decentralization policy in 2000-2016, cash and remittance were decreased, but cash made-home had increased trend because of business opportunities at the village level. The educated in- migrant people positively impacted knowledge sharing and had no negative impact on forest and land. Even though out-migration reduce agricultural workers but it did not reduce agricultural production. The prospect of out-migration to seek a good job out-side Indonesia showed the respondents no longer interested because of Indonesia's availability of opportunities after the decentralization policy since 2000 .

\section{REFERENCES}

[1] A. Howell, Impacts of Migration and Remittances on Ethnic Income Inequality in Rural China, World Development, 94, 2017, pp. 200-211. DOI: 10.1016/j.worlddev.2017.01.005.

[2] A.A. Bandey, F.A. Rather, Socio-economic and political motivations of Russian out-migration from Central Asia, Journal of Eurasian Studies 4(2), 2013. Pp. 146-153. DOI: 10.1016/j.euras.2013.03.004

[3] A. Stratan, M. Chistruga, Economic Consequences of Remittances, Case of Moldova, Procedia Economics and Finance, 3(12), 2012, pp. 11911195. DOI: 10.1016/S2212-5671(12)00295-X.

[4] M.L. Flahaux, H. De Haas, African migration: trends, patterns, drivers, Comparative Migration Studies, 4(1), 2016. DOI: 10.1186/s40878-0150015-6

[5] W.T. Widayanti, S. Widodo, Pemerataan dan Pemanfaatan Pendapatan Keluarga Petani Hutan,
Journal of Community Forest Center for Community Forestry Studies, 1(1), 1999, p. 21.

[6] H. Simon, Hutan Jati dan Kemakmuran, Aditya Media, Yogyakarta, 1993.

[7] F. Ellis, A Livelihoods Approach to Migration and Poverty Reduction, The Journal of Development of Studies, 36, 2003, Available at: https://www.researchgate.net/publication/2285936 $\underline{69}$

[8] A.H. Dharmawan, Pendekatan-Pendekatan Pembangunan Pedesaan dan Pertanian: Klasik dan Kontemporer, 2006, Available at: https://www.scribd.com/doc/34146650/TeoriTeori-Pembangunan-Klasik-Kontemporer

[9] H. De Haas, Migration and Development: A Theoretical Perspective, International Migration Review, 44, 2008, pp. 227-264. DOI: 10.1111/j.1747-7379.2009.00804.x

[10] E.P. Mulyoutami, E. Fauziyah, T.S. Widyaningsih, D. Awalina, B. Lusiana, Perantau dan Pengelola Kebun. Sebuah Kajian Migrasi di Kabupaten Ciamis, Jawa Barat, agris.fao.org., 2015. Available at: www.worldagroforestry.org/sea/Publications

[11] R. King, D. Mata-Codesal, J. Vullnetari, Migration, Development, Gender and the "Black Box" of Remittances: Comparative Findings from Albania and Ecuador, Comparative Migration Studies, 1(1), 2013, pp. 69-96. DOI: 10.5117/CMS2013.1.KING.

[12] K. Hirvonen, H.B. Lilleør, Going back home: Internal return migration in rural Tanzania, World Development, 70, 2015, pp. 186-202. DOI: 10.1016/j.worlddev.2015.01.007.

[13] H. Qin, Rural-to-Urban Labor Migration, Household Livelihoods, and the Rural Environment in Chongqing Municipality, Southwest China, Human Ecology, 38(5), 2010, pp. 675-690. DOI: $10.1007 / \mathrm{s} 10745-010-9353-\mathrm{z}$.

[14] C. Amuedo-Dorantes, S. Pozo, Remittance income uncertainty and asset accumulation, IZA Journal of Labor and Development, 3(1), 2014, pp. 1-24. DOI: $10.1186 / 2193-9020-3-3$ 